\title{
Assessment of Wind Energy Potential in the Sudanese Zone in Chad
}

\author{
Marcel Hamda Soulouknga ${ }^{1}$, Sunday Olayinka Oyedepo², Serge Yamigno Doka ${ }^{3}$, \\ Timoleon Crepin Kofane ${ }^{4,5}$
}

\author{
${ }^{1}$ Department of Renewable Energy, the Higher Institute of the Sahel, University of Maroua, Maroua, Cameroon \\ ${ }^{2}$ Mechanical Engineering Department, Covenant University, Ota, Nigeria \\ ${ }^{3}$ Department of Physics, Faculty of Science, University of Ngaoundere, Ngaoundere, Cameroon \\ ${ }^{4}$ Department of Physics, Faculty of Science, the University of Yaounde I, Yaounde, Cameroon \\ ${ }^{5}$ Centre d'Excellence Africain en Technologie de l'Information et de la Communication, Yaounde, Cameroon \\ Email: marcelhamda@yahoo.fr
}

How to cite this paper: Soulouknga, M.H., Oyedepo, S.O., Doka, S.Y. and Kofane, T.C. (2017) Assessment of Wind Energy Potential in the Sudanese Zone in Chad. Energy and Power Engineering, 9, 386-402. https://doi.org/10.4236/epe.2017.97026

Received: April 24, 2017

Accepted: July 24, 2017

Published: July 27, 2017

Copyright (c) 2017 by authors and Scientific Research Publishing Inc. This work is licensed under the Creative Commons Attribution International License (CC BY 4.0).

http://creativecommons.org/licenses/by/4.0/

\section{(c) (i) Open Access}

\begin{abstract}
In this study, wind characteristics and wind power potential are analyzed for three meteorological stations in the Sudanese zone of Chad for the period of 35 years (from 1975 to 2010). Assessment of the wind power potential was carried out using the two parameters of Weibull distribution. Results of the study shows that the average annual wind speeds at $10 \mathrm{~m}$ above ground for Moundou, Pala and Sarh are 2.69, 2.33 and $1.91 \mathrm{~m} / \mathrm{s}$, respectively. The mean annual value of the Weibull shape parameter $k$ and scale parameter $c$ range from 2.376 to 3.255 and 2.099 to 3.007 , respectively. The maximum annual power density of $204.85 \mathrm{~W} / \mathrm{m}^{2}$ was obtained at Moundou. Results of this study further shows that the selected locations are not suitable for large-scale wind energy production at $10 \mathrm{~m}$ altitude. However, by extrapolation, assessment of wind speed at $67 \mathrm{~m}$ altitude combines with wind turbine Vestas $2 \mathrm{MW} / 80$ that adapts to the Sudanese local conditions, and the wind power potential can be exploited for water pumping, heating and production of electricity.
\end{abstract}

\section{Keywords}

Assessment, Wind Energy, Weibull Distribution, Electricity, Sudanese Zone

\section{Introduction}

Energy plays a significant role in human and economic development. Demand for energy is growing exponentially. In addition, conventional energy resources are limited and their use contribute major proportion to environmental pollution [1] [2] [3] [4] [5]. The world total energy demand is increasing faster than 
the increase of total population day-by-day. To satisfy this energy demand, it is necessary to embark on alternative sources such as renewable energies which are clean sources of energy and nonpolluting [6] [7]. Among these renewable energies is wind energy. The wind energy production in the world is about $318.510 \mathrm{MW}$ as at 2013 [8]. The highest growth rate of wind energy was $64.3 \%$ and this occurred in 1999. It is now recognized as the source of energy which develops most quickly on a worldwide scale. As a result of technologies development in the recent years, the production of electricity by wind power technology has reached a high level of technological maturity and industrial reliability [9] [10].

The knowledge of wind characteristics based on the wind velocity is essential, not only for the evaluation of the wind power potential but also for the dimensioning of the wind power stations and the selection of suitable choice of the aerogenerators [11] [12].

Chad is a country with $80 \%$ of her population living in rural area, without a particular grid system of electricity. Only $2 \%$ to $4 \%$ of the population has access to electricity. Therefore, renewable energy is fitted to its development and the well-being of its population [13]. Due to the fact that the country has no devices for capturing parameters for evaluating the solar and wind potentials, in this study some data were gotten from satellite measurement. Chad has a significant natural energy potential. In particular, the exploitation of the solar energy and wind power could help to achieve sustainable energy development. Presently, to the best knowledge of the authors, there have been no much research works on assessment of solar and wind energy potentials in Chad. This study aims at assessment of the potential of wind energy in the Sudanese zone of Chad using Weibull distribution.

\section{Wind Data and Analysis}

\subsection{Wind Speed Data}

Vast of $1,284,000 \mathrm{~km}^{2}$, Chad extends between $7^{\circ}$ and $24^{\circ}$ of north latitude and between $14^{\circ}$ and $24^{\circ}$ of longitude east. A country in central Africa at an average altitude of 200 meters above the sea, Chad is totally enclave. It is surrounded by six countries: in the north Libya, in the east Sudan, in the south the Central African Republic and in the West Cameroon, Nigeria and Niger. There are three major climatic zones in Chad: the Saharan Zone in the North, the Sahelian zone in the Center and the Sudanese zone in the South. In these three climatic zones of Chad, the speed of the wind was measuredin the weather observation stations. The data for this study were obtained from the division of Climatology of Chad National Meteorological General Direction (Figure 1). The velocity measurements of the wind were made at $10 \mathrm{~m}$ height. The geographical coordinates of the selected sites are given in Table 1 .

\subsection{Data Analysis}

The Weibull distribution is usually used, accepted and recommended in the literature. It proved not only adapted for the description of the statistical properties 


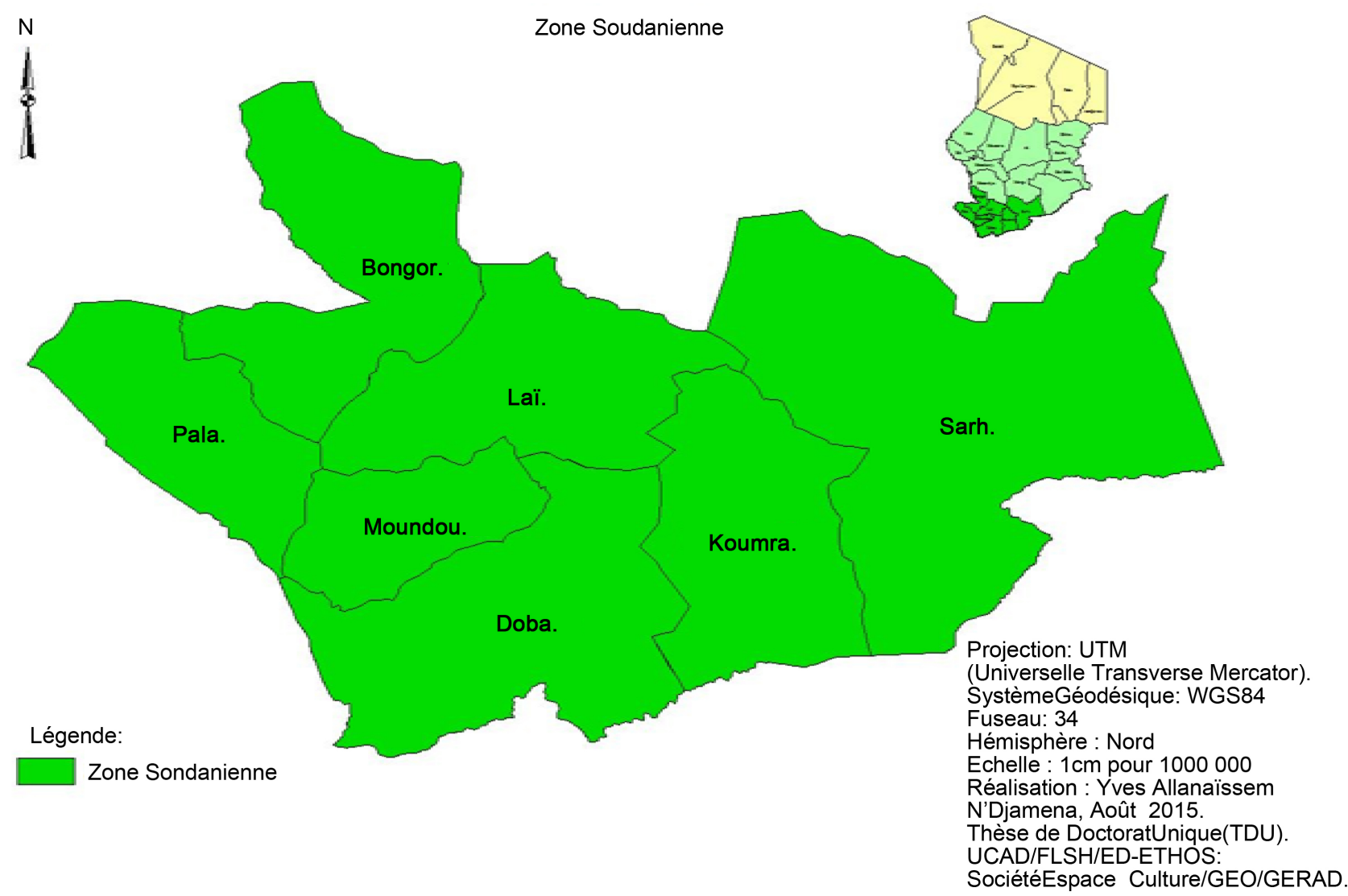

Figure 1. Sudanese zone in Chad [14].

Table 1. Geographical coordinates of stations used in the study.

\begin{tabular}{lccccc}
\hline Station & Longitude & Latitude & Elevation & Period of & $\begin{array}{c}\text { Height of } \\
\text { the }\end{array}$ \\
\hline & ${ }^{\bullet} \mathrm{E}$ & ${ }^{\circ} \mathrm{N}$ & $(\mathrm{m})$ & measurement (year) & Mast (m) \\
\hline Moundou & 16.4 & 8.37 & 420 & 20 & 10 \\
Pala & 14.55 & 9.22 & 420 & 30 & 10 \\
Sarh & 18.23 & 9.9 & 364 & 20 & 10 \\
\hline
\end{tabular}

of the wind but gives a good agreement with the experimental data [15]. The function of Weibull distribution with two parameters in particular the shape factor $k$ (without dimension) and the scale factor $c(\mathrm{~m} / \mathrm{s})$ for a place at a particular time is given by [16] [17] [18] [19]:

$$
f(v)=\left(\frac{k}{c}\right) \cdot\left(\frac{v}{c}\right)^{k-1} \cdot \exp \left(-\left(\frac{v}{c}\right)^{k}\right),(k>0, v>0, c>1)
$$

where $v$ the speed of the wind $(\mathrm{m} / \mathrm{s}), k$ is an adimensional factor of form which characterizes the frequency distribution and $C$ is the scale factor which is the dimension speed.

The determination of $k$ and $c$ called parameters of Weibull makes it possible to know the distribution of the winds for a given site. Once these parameters are determined, the mean velocity of the wind is calculated according to the follow- 
ing expression [19] [20]:

$$
F(v)=1-\exp \left(-\left(\frac{v}{c}\right)^{k}\right)
$$

where $F(v)$ represents cumulative distribution function. The energy pattern factor method is related to the averaged data of wind speed and is defined by the following equations [21] [22] [23]:

$$
\begin{gathered}
E_{p f}=\frac{\overline{V^{3}}}{\bar{V}^{3}}=\frac{\left(\frac{1}{n} \sum_{i=1}^{n} v_{i}^{3}\right)}{\left(\frac{1}{n} \sum_{i=1}^{n} \bar{v}_{i}\right)^{2}} \\
k=\frac{1+3.69}{\left(E_{p f}\right)^{2}} \\
\bar{V}=C\left(1+\frac{1}{k}\right) \\
\sigma=c\left[\Gamma\left(1+\frac{2}{k}\right)-\Gamma^{2}\left(1+\frac{1}{k}\right)\right]^{1 / 2}
\end{gathered}
$$

where, $E_{p f}$ is the energy pattern factor and is the gamma function defined by

$$
\begin{gathered}
\Gamma(x)=\int_{0}^{\infty} t^{x-1} \exp (-t) \mathrm{d} t \\
\Gamma(x)=(\sqrt{2 \pi x})\left(x^{x-1}\right)\left(\mathrm{e}^{-x}\right)\left(1+\frac{1}{12 x}+\frac{1}{288 x^{2}}-\frac{1}{51840 x^{3}}+\cdots\right)
\end{gathered}
$$

\subsection{The Probable Wind Speed}

The most probable speed of wind can be determined from the shape parameter and scale parameter of Weibull distribution function. The speed of the most probable wind is obtained as [24]:

$$
V_{m p}=c\left(1-\frac{1}{k}\right)^{1 / k}(\mathrm{~m} / \mathrm{s})
$$

\subsection{Maximum Energy Carrying by the Wind Speed}

Determination of the maximum speed of wind energy can be calculated from the shape parameter and scale parameter of Weibull distribution function. The wind speed carrying the maximum wind power can be to calculate as [25] [26]:

$$
V_{\max . E}=c\left(1+\frac{2}{k}\right)^{1 / k}(\mathrm{~m} / \mathrm{s})
$$

\subsection{Wind Power Density}

The power density of the wind power is the most significant characteristic of the wind. It represents the quantity of energy produced by the wind. Assuming that $A$ is the cross sectional area through which the wind spins out perpendicularly. The power of the wind is given by the following relation [27] [28] [29]: 


$$
P(V)=\frac{1}{2} \rho A v_{m}^{3}
$$

where, $\rho$ is the density of air which depends on the pressure (elevation), temperature and moisture content present. In this study, it is assumed to be constant since its variation does not affect the calculation of resource of the wind in a significant way [30] [31]. By using the Weibull probability density function, the density of power of wind (by unit of surface) can be obtained by using the following equation [19] [32]:

$$
P(V)=\frac{P(V)}{A}=\frac{1}{2} \rho c^{3} \Gamma\left(1+\frac{3}{k}\right)
$$

$\rho$ is often written in a simple form [25]: $\rho=\rho_{0}-1.194 \times 10^{-4} \times H_{m}$ where, $H_{m}=$ site elevation in meters. The air density value at sea level is $\rho_{0}=1.225 \mathrm{~kg} / \mathrm{m}^{3}$.

\subsection{Extrapolation of Wind Speed and Wind Power at Different Hub Height}

The precise evaluation of the wind potential for a given site requires the knowledge the speed of the wind to various heights. The standard height of measurement is generally of $10 \mathrm{~m}$, but during a prospection of a site, in order to draw up a wind project, it is preferable to take measures with two or three levels for one period at least of a year in order to know the evolution the speed of the wind at altitudes representing an energy interest. To model the vertical profile is written by the law of power by the expression [12] [22] [33] [34] [35] [36] [37]:

$$
v\left(z_{2}\right)=v\left(z_{10}\right)\left(\frac{\mathrm{z}_{2}}{\mathrm{z}_{10}}\right)^{\alpha_{1}}
$$

where,

$v\left(z_{2}\right)$ is wind speed at the hub height $z_{2}$,

$v\left(z_{10}\right)$ is wind speed at the original height $z_{10}$,

$\alpha_{1}$ is surface roughness coefficient, it is determined from following expressions:

$$
\alpha_{1}=\frac{\left[0.37-0.088 \ln \left(v_{10}\right)\right]}{\left[1-0.088 \ln \left(\frac{z_{10}}{10}\right)\right]}
$$

The Weibull parameters at measurement height are related to the parameters at the wind turbine height by the following expressions:

$$
\begin{gathered}
c(h)=c_{0}\left(\frac{h}{h_{0}}\right)^{n} \\
k(h)=k_{0}\left[1-0.088 \ln \left(\frac{h_{0}}{10}\right)\right] /\left[1-0.088 \ln \left(\frac{h}{10}\right)\right]
\end{gathered}
$$

where $c_{0}$ and $k_{0}$ are the scale factor and shape parameter respectively at the measurement height $h_{0}$ and $h$ is the hub height. 
In addition, for a height less than $130 \mathrm{~m}$, the power density of the wind above the ground level is given by:

$$
P_{h}=P_{10}\left(\frac{h}{10}\right)^{3 \alpha_{1}}
$$

where $P_{10}$ is the corrected power available in wind at a height of $10 \mathrm{~m}$.

\subsection{Power Output of Wind Turbine and Capacity Factor}

In order to determine which wind turbine is the most efficient and best suited to the area studied, three turbines characterized by a starting speed lower than the average annual speed of the site were selected. Two of the machines are high powers and one of low power. Wind turbine performance is estimated with the capacity factor $\left(C_{f}\right)$ which represents the fraction of the average power delivered by the wind turbine $\left(P_{e, a v e}\right)$ to the nominal power of the wind turbine $\left(P_{e R}\right)$. The mean power $\left(P_{e, a v e}\right)$ and the capacity factor of the wind turbines are calculated using the following equations [38] [39]

$$
\begin{aligned}
& P_{e}=\left\{\begin{array}{lc}
0 & \left(v<v_{c}\right) \\
P_{e R} \frac{v^{k}-v_{c}^{k}}{v_{R}^{k}-v_{c}^{k}} & \left(v_{c} \leq v \leq v_{R}\right) \\
P_{e R} & \left(v_{R} \leq v \leq v_{F}\right) \\
0 & \left(v_{F}<v\right)
\end{array}\right. \\
& P_{e, a v e}=P_{e R}\left\{\frac{\mathrm{e}^{-\left(\frac{v_{c}}{c}\right)^{k}}-\mathrm{e}^{-\left(\frac{v_{R}}{c}\right)^{k}}}{\left(\frac{v_{R}}{c}\right)^{k}-\left(\frac{v_{r}}{c}\right)^{k}}-\mathrm{e}^{-\left(\frac{v_{F}}{c}\right)^{k}}\right\}
\end{aligned}
$$

The capacity factor $\left(C_{f}\right)$ of a wind turbine installed at a given site is defined as the ratio of the output power to the maximum theoretical output of the wind turbine, if it operates at its nominal (maximum) capacity during the whole of the 8760 hours of the year $(365 \mathrm{~d} \times 24 \mathrm{~h})$ or 720 hours of the month $(30 \mathrm{~d} \times 24 \mathrm{~h})$. In practice, the capacity factor varies between $25 \%$ and $40 \%$. A capacity factor of 0.4 or more indicates that the adaptation of the system to the wind speed is very good. The capacity factor is given by [40] [41] [42]

$$
C_{f}=\frac{P_{e, a v e}}{P_{e R}}
$$

\section{Results and Discussion}

In this study, wind speed data analysis was carried out using MATLAB and Ex$\mathrm{cel}^{\Phi}$. The dimensionless Weibull scale parameter $\mathrm{c}$ and shape parameter $k$ were estimated using the $E_{p f}$ method.

In addition, Weibull mean speed $V_{m}$, shape parameter $(k)$, and scale parameter (c) for the three selected locations Moundou, Pala and Sarh are summarized in Table 2.

Table 2 shows the various speed and Weibull parameters for the three sites of 
Table 2. Parameters of Weibull.

\begin{tabular}{lccc}
\hline Sites & $V_{m}(\mathrm{~m} / \mathrm{s})$ & $\boldsymbol{k}(-)$ & $\boldsymbol{c}(\mathrm{m} / \mathrm{s})$ \\
\hline Moundou & 2.69 & 3.101 & 3.007 \\
Pala & 2.33 & 3.255 & 2.602 \\
Sarh & 1.91 & 2.376 & 2.099 \\
\hline
\end{tabular}

Chad. It is noticed that Moundou and Pala are the two sites for which the speeds are respectively 2.69 and $2.33 \mathrm{~m} / \mathrm{s}$. Sarh is the site of the Sudanese zone for which the speed of the wind is lowest, $1.91 \mathrm{~m} / \mathrm{s}$. Pala, the site which possesses the highest parameter of form that is 3.225 . Whereas, the site with the lowest parameter of form is Sarh with $k=2.376$.

Table 3 presents the different values of the annual averages of wind speed, power density and energy produced. The lowest wind speed is observed at Sarh $(1.908 \mathrm{~m} / \mathrm{s})$ and the highest at Moundou $(2.692 \mathrm{~m} / \mathrm{s})$. On the other hand, the lowest power density and energy are observed in Pala, with respective values of $11.212 \mathrm{~W} / \mathrm{m}^{2}$ and $97,816 \mathrm{kWh} / \mathrm{m}^{2} /$ year.

Figure 2 shows the different values of the speed obtained after extrapolation. Thus, this figure shows that for the three cities of the Sudanese zone, Moundou is the city where the wind speed is highest $(4.608 \mathrm{~m} / \mathrm{s})$ at $67 \mathrm{~m}$ altitude. On the other hand, at the same height, the lowest speed recorded at Sarh was $3.464 \mathrm{~m} / \mathrm{s}$.

Figure 3 shows that the largest power recorded at Moundou are $36.616 \mathrm{~W} / \mathrm{m}^{2}$, $41.068 \mathrm{~W} / \mathrm{m}^{2}$ and $43.858 \mathrm{~W} / \mathrm{m}^{2}$ at $30 \mathrm{~m}, 50 \mathrm{~m}$ and $67 \mathrm{~m}$ altitude, respectively. At these same heights, the minimum powers were recorded at Sarh: $20.643 \mathrm{~W} / \mathrm{m}^{2}$, $25.815 \mathrm{~W} / \mathrm{m}^{2}$ and $29.344 \mathrm{~W} / \mathrm{m}^{2}$, respectively.

Figure 4 presents the different values of the mean wind speed at $10 \mathrm{~m}$ altitude for the three selected cities. The minimum speed of $1.91 \mathrm{~m} / \mathrm{s}$ was recorded at Sarh while the maximum speed recorded was $2.69 \mathrm{~m} / \mathrm{s}$ at Moundou.

Figure 5 shows that at $50 \mathrm{~m}$ altitude, Moundou is the site where the wind speed is highest. On the other hand, the lowest speed is at Sarh.

Figure 6 shows the different variations in wind speed at $30 \mathrm{~m}$ altitude for the three selected sites, of which Moundou appears to be most favorable site.

As for Figure 7, it presents respectively the different monthly values of the wind speed at $67 \mathrm{~m}$ altitude. From Figures 4-7, it can be seen that the wind speed varies as a function of altitude and Moundou is the windiest site of the Sudanese zone of Chad.

Table 4 presents the monthly and annual changes in Weibull parameters $(k$ and $c$ ) estimated at $10 \mathrm{~m}$ above ground level. The minimum monthly value of the Weibull $(k)$ form parameter of 1.194 is observed at Sarh in January and the maximum value 3.983 at Pala in July. The monthly scale parameter $(c)$ has a minimum value of $1.564 \mathrm{~m} / \mathrm{s}$ at Sarh in August and September and the highest value is $3.702 \mathrm{~m} / \mathrm{s}$ in April at Moundou. The annual shape parameter varied between 2.376 at Sarh and 3.255 at Pala, while the annual scale parameter varied between $2.099 \mathrm{~m} / \mathrm{s}$ at Sarh and 3.007 at Moundou. As a result, it is obvious that the shape parameter $(k)$ has a much greater variation; this implies that the wind 
speed of the different zones does not vary enough with respect to the average speed.

The monthly and annual values of the most probable wind speed variations $\left(V_{m p}\right)$ and the highest energy velocity $\left(V_{\max E}\right)$ at a height of $10 \mathrm{~m}$ are shown in Table 5. Thus, in Moundou, the highest annual values of $V_{m p}$ and $V_{\max E}$ are 2.647

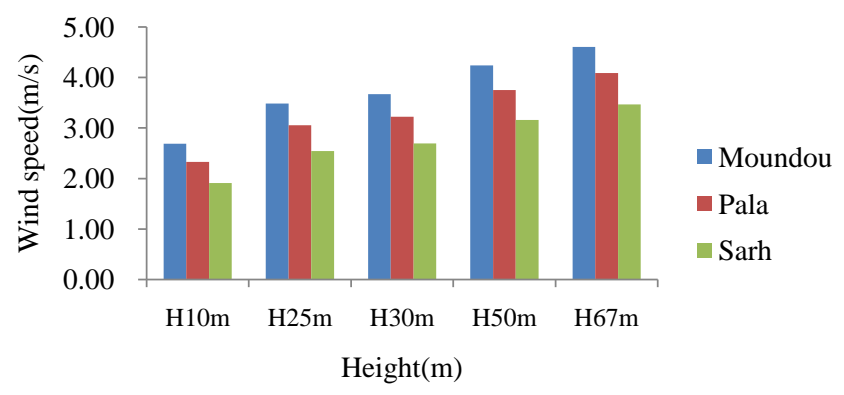

Figure 2. Annual mean wind throughout the year at the heights from 10 to $67 \mathrm{~m}$.

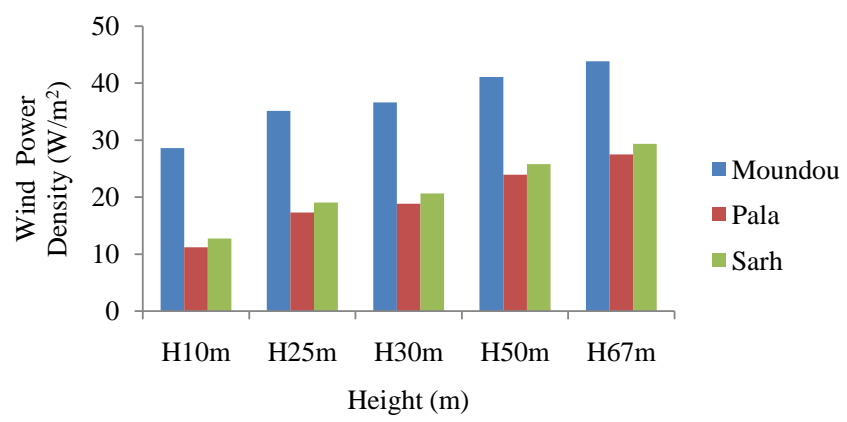

Figure 3. Annual mean wind power throughout the year at the heights from 10 to $67 \mathrm{~m}$.

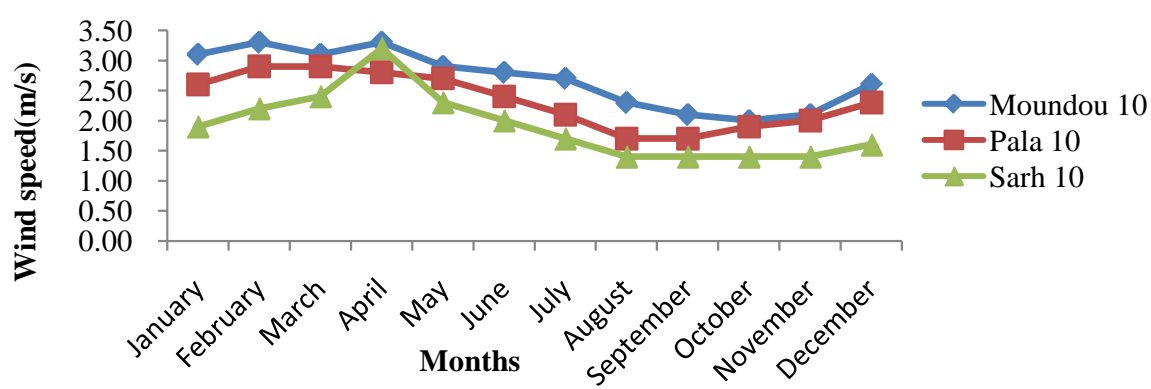

Figure 4. Mean wind speed for Moundou, Pala and Sarh at height $10 \mathrm{~m}$.

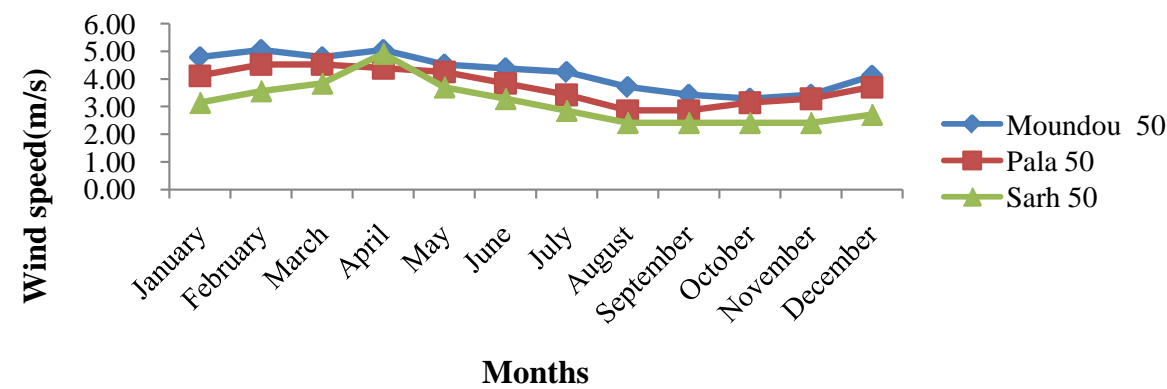

Figure 5. Mean wind speed for Moundou, Pala and Sarh at $50 \mathrm{~m}$ height. 
$\mathrm{m} / \mathrm{s}$ and $3.539 \mathrm{~m} / \mathrm{s}$, respectively, while Sarh and Pala have the lowest annual values of $V_{m p}$ and $V_{\max E}$ which are $1.296 \mathrm{~m} / \mathrm{s}$ and $3.042 \mathrm{~m} / \mathrm{s}$, respectively. The most likely wind speed $\left(V_{m p}\right)$ varies from $0.441 \mathrm{~m} / \mathrm{s}$ at Sarhin in January to $3.286 \mathrm{~m} / \mathrm{s}$ at Moundou in February, while the highest wind speed $\left(V_{\max E}\right)$ varies from 1.829

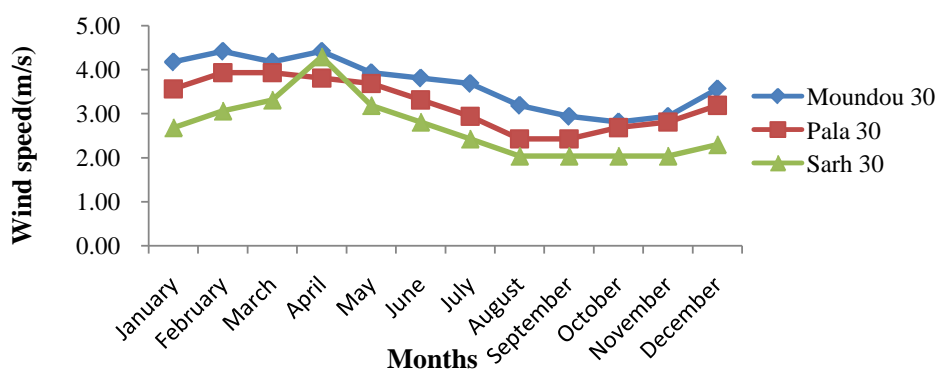

Figure 6. Mean wind speed for Moundou, Pala and Sarh at height $30 \mathrm{~m}$.

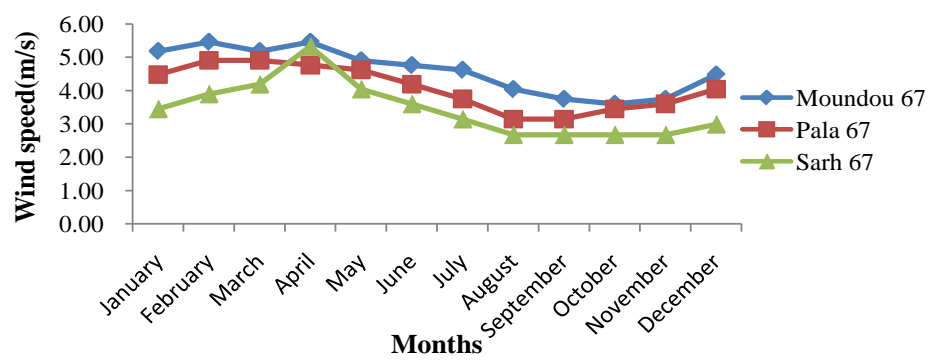

Figure 7. Mean wind speed for Moundou, Pala and Sarh at height $67 \mathrm{~m}$.

Table 3. Annual wind characteristics for three sites at $10 \mathrm{~m}$ height for the period of $1975-2010$

\begin{tabular}{lccc}
\hline Locations & $\begin{array}{c}\text { Annual mean } \\
\text { wind speed }(\mathrm{m} / \mathrm{s})\end{array}$ & $\begin{array}{c}\text { Annual mean power } \\
\text { density }\left(\mathrm{W} / \mathrm{m}^{2}\right)\end{array}$ & $\begin{array}{c}\text { Annual energy } \\
\left(\mathrm{KWh} / \mathrm{m}^{2} / \text { year }\right)\end{array}$ \\
\hline Moundou & 2.692 & 17.071 & 148.85 \\
Pala & 2.333 & 11.212 & 97.816 \\
Sarh & 1.908 & 12.762 & 110.799 \\
\hline
\end{tabular}

Table 4. Monthly and annual variation of Weibull parameters $(k$ and $c)$ for the selected points at $10 \mathrm{~m}$ heights.

\begin{tabular}{lcccccc}
\hline Month & \multicolumn{2}{c}{ Moundou } & \multicolumn{2}{c}{ Pala } & \multicolumn{2}{c}{ Sarh } \\
\hline January & $\boldsymbol{k}$ & $\boldsymbol{c}$ & $\boldsymbol{k}$ & $\boldsymbol{c}$ & $\boldsymbol{c}$ \\
February & 3.613 & 3.439 & 3.193 & 2.903 & 1.194 & 2.017 \\
March & 3.242 & 3.682 & 3.539 & 3.221 & 1.232 & 2.353 \\
April & 3.256 & 3.458 & 3.143 & 3.24 & 1.307 & 2.601 \\
May & 2.876 & 3.702 & 3.205 & 3.126 & 1.621 & 3.573 \\
June & 3.028 & 3.246 & 3.482 & 3.001 & 3.396 & 2.56 \\
July & 3.144 & 3.128 & 3.277 & 2.676 & 3.73 & 2.215 \\
August & 3.306 & 3.009 & 3.983 & 2.317 & 3.741 & 1.882 \\
September & 2.705 & 2.586 & 3.559 & 1.888 & 3.144 & 1.564 \\
October & 3.058 & 2.349 & 3.108 & 1.9 & 3.144 & 1.564 \\
November & 2.397 & 2.256 & 3.646 & 2.107 & 2.924 & 1.569 \\
December & 3.235 & 2.343 & 2.64 & 2.25 & 1.678 & 1.567 \\
Annual & 3.355 & 2.896 & 2.263 & 2.596 & 1.294 & 1.731 \\
\hline
\end{tabular}


Table 5. Average monthly and annual values of the most probable wind speed $\left(V_{m p}\right)$ and maximum energy carrying wind speed $\left(V_{\max E}\right)$ at $10 \mathrm{~m}$ heights.

\begin{tabular}{lcccccc}
\hline & \multicolumn{2}{c}{ Moundou } & \multicolumn{2}{c}{ Pala } & \multicolumn{2}{c}{ Sarh } \\
\hline Month & $V_{m p}$ & $V_{\max E}$ & $V_{m p}$ & $V_{\max E}$ & $V_{m p}$ & $V_{\max E}$ \\
\hline January & 3.144 & 3.885 & 2.581 & 3.381 & 0.441 & 4.597 \\
February & 3.286 & 4.27 & 2.932 & 3.655 & 0.606 & 5.151 \\
March & 3.089 & 4.006 & 2.869 & 3.79 & 0.859 & 5.29 \\
April & 3.191 & 4.447 & 2.781 & 3.636 & 1.976 & 5.867 \\
May & 2.843 & 3.838 & 2.723 & 3.419 & 2.31 & 2.934 \\
June & 2.77 & 3.659 & 2.395 & 3.095 & 2.037 & 2.485 \\
July & 2.699 & 3.472 & 2.155 & 2.566 & 1.732 & 2.111 \\
August & 2.18 & 3.173 & 1.72 & 2.14 & 1.385 & 1.829 \\
September & 2.064 & 2.77 & 1.677 & 2.23 & 1.385 & 1.829 \\
October & 1.801 & 2.905 & 1.929 & 2.375 & 1.36 & 1.875 \\
November & 2.09 & 2.719 & 1.879 & 2.786 & 0.914 & 2.502 \\
December & 2.606 & 3.329 & 2.006 & 3.435 & 0.551 & 3.561 \\
Annual & 2.647 & 3.539 & 2.304 & 3.042 & 1.296 & 3.336 \\
\hline
\end{tabular}

$\mathrm{m} / \mathrm{s}$ at Sarh in August and September to $5.867 \mathrm{~m} / \mathrm{s}$ in April.

Depending on the wind speed classes, the frequency distribution of the measured wind speed has been established and presented in Figure 8 while the cumulative distribution of the frequencies of the measured wind speed is presented in Figure 9.

Table 6 shows the characteristics of selected wind turbines. In order to bring out the model of the park with a real wind turbine, three types of wind turbine, 1 medium power and 2 high powers were selected.

Table 7 shows the monthly values of average power $\left(P_{\text {OUT }}\right)$ delivered by the BONUS $300 \mathrm{~kW} / 33$ wind turbine, capacity factor $\left(C_{f}\right)$ and cumulative energy production $\left(E_{W T}\right)$ for the selected three sites.

Table 8 shows the monthly values of average power $\left(P_{\text {OUT }}\right)$ delivered by the BONUS $1 \mathrm{MW} / 54$ wind turbine, capacity factor $\left(C_{f}\right)$ and cumulative energy production $\left(E_{W T}\right)$ for the selected three sites.

Table 9 shows the monthly values of average power $\left(P_{\text {OUT }}\right)$ delivered by the BONUS VESTAS $2 \mathrm{MW} / \mathrm{V} 80$ wind turbine, capacity factor $\left(C_{f}\right)$ and cumulative energy production $\left(E_{W T}\right)$ for the three cities.

Table 10 presents the annual performance and capacity factor of the selected wind turbine for the three selected locations. Note that the Bonus $300 \mathrm{~kW} / 33$ wind turbine has a good capacity factor $38.50 \%$ for the city of Sarh and Bonus $1 \mathrm{MW} / 50,25.73 \%$ for the city of Moundou.

Table 11 presents the average monthly energy for the selected three sites in the Sudanese zone of Chad. The lowest and highest wind energy densities were observed at Sarh for the three selected sites, respectively, at $1.598 \mathrm{kWh} / \mathrm{m}^{2}$ / month and $33.966 \mathrm{kWh} / \mathrm{m}^{2} /$ month, respectively. In addition, the highest annual energy of $148.85 \mathrm{kWh} / \mathrm{m}^{2} /$ year was recorded in Moundou and the lowest of 
$97.816 \mathrm{kWh} / \mathrm{m}^{2} /$ year in Pala. Table 12 presents the standard deviation of wind speed for the selected three locations.

It is observed in Table 12 that the city in the Sudanese zone of Chad having a small gap of 0.6 is Sarh and high gap of 0.92 is Moundou.

Table 13 presents the different seasonal values of the Weibull parameters. It is seen that in winter the parameter of form $k$ for the site of Sarh is 1.24 which implies that the wind speed in this station is very variable with respect to the average speed. Moreover, in the spring the scale factor at Moundou is $3.49 \mathrm{~m} / \mathrm{s}$,

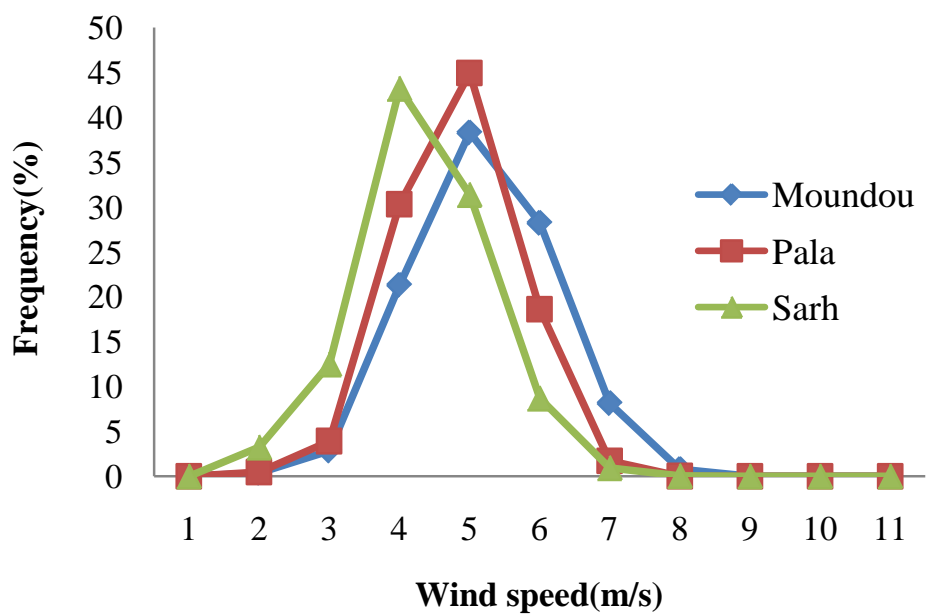

Figure 8. Frequency distribution of measured wind speed.

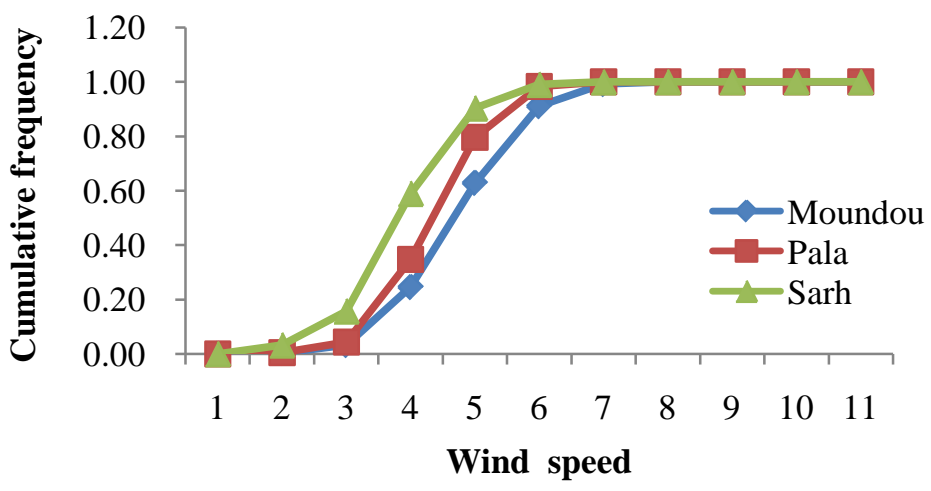

Figure 9. Whole year cumulative frequency distribution of measured wind speed.

Table 6. Characteristics of the selected wind turbines.

\begin{tabular}{cccc}
\hline Characteristics & Bonus $\mathbf{3 0 0} \mathbf{k W / 3 3}$ & BONUS 1 MW/54 & Vestas 2 MW/80 \\
\hline hub height $(\mathrm{m})$ & 30 & 50 & 67 \\
Rated power $P_{r}(\mathrm{~kW})$ & 300 & 1000 & 2000 \\
Diameter & 33.4 & 54.2 & 80 \\
Cut-in wind speed $V_{c}(\mathrm{~m} / \mathrm{s})$ & 3 & 3 & 4 \\
Rated wind speed $V_{r}(\mathrm{~m} / \mathrm{s})$ & 14 & 15 & 16 \\
Cut-off wind speed $V_{f}(\mathrm{~m} / \mathrm{s})$ & 25 & 25 & 25 \\
\hline
\end{tabular}


which implies that the site is windy. The lowest average speed is $1.4 \mathrm{~m} / \mathrm{s}$ at Sarh in the autumn, while the highest at $4.1 \mathrm{~m} / \mathrm{s}$ is observed at Moundou in the spring. Thus, it can be concluded that Moundou remains a site where the characteristics of the wind are important and favorable throughout the four seasons.

\section{Conclusions}

In this study, the monthly and annual distributions of wind distribution and

Table 7. Monthly variations of mean turbine BONUS $300 \mathrm{~kW} / 33$.

\begin{tabular}{lccccccccc}
\hline \multicolumn{3}{c}{ Moundou } & \multicolumn{3}{c}{ Pala } & & & Sarh & \\
\hline Month & $P_{\text {OUT }}$ & $C_{f}(\%)$ & $\begin{array}{c}E_{W T} \\
(\mathrm{kWh} / \\
\text { mon })\end{array}$ & $P_{\text {OUT }}$ & $C_{f}(\%)$ & $\begin{array}{c}E_{W T} \\
(\mathrm{kWh} /\end{array}$ & $P_{\text {OUT }}$ & $C_{f}(\%)$ & $\begin{array}{c}E_{W T} \\
\text { mon })\end{array}$ \\
\hline January & 4.14 & $1.38 \%$ & 2977.98 & 3.32 & $1.11 \%$ & 2387.04 & 17.64 & $5.88 \%$ & $12,697.74$ \\
February & 7.78 & $2.59 \%$ & 5603.73 & 3.43 & $1.14 \%$ & 2472.13 & 23.05 & $7.68 \%$ & $16,593.8$ \\
March & 6.11 & $2.04 \%$ & 4400.9 & 5.4 & $1.8 \%$ & 3889.52 & 25.39 & $8.46 \%$ & $18,283.7$ \\
April & 11.3 & $3.77 \%$ & 8133.07 & 4.4 & $1.47 \%$ & 3168.83 & 34.44 & $11.48 \%$ & $24,795.38$ \\
May & 6.16 & $2.05 \%$ & 4432.26 & 2.72 & $0.91 \%$ & 1959.69 & 1.46 & $0.49 \%$ & 1054 \\
June & 4.72 & $1.57 \%$ & 3399.19 & 2.1 & $0.7 \%$ & 1514.54 & 0.41 & $0.14 \%$ & 292.07 \\
July & 3.37 & $1.12 \%$ & 2426.52 & 0.37 & $0.12 \%$ & 268.97 & 0.12 & $0.04 \%$ & 84.01 \\
August & 3.78 & $1.26 \%$ & 2721.72 & 0.17 & $0.06 \%$ & 121.32 & 0.08 & $0.03 \%$ & 54.02 \\
September & 1.52 & $0.51 \%$ & 1093.36 & 0.41 & $0.14 \%$ & 293.37 & 0.08 & $0.03 \%$ & 54.02 \\
October & 3.33 & $1.11 \%$ & 2394.39 & 0.33 & $0.11 \%$ & 238.28 & 0.14 & $0.05 \%$ & 97.68 \\
November & 1.16 & $0.39 \%$ & 838.35 & 2.28 & $0.76 \%$ & 1640.81 & 2.89 & $0.96 \%$ & 2078.49 \\
December & 2.71 & $0.9 \%$ & 1951.21 & 6.84 & $2.28 \%$ & 4924.41 & 9.82 & $3.27 \%$ & 7073.74 \\
\hline
\end{tabular}

Table 8. Monthly variations of mean turbine BONUS 1 MW/54.

\begin{tabular}{|c|c|c|c|c|c|c|c|c|c|}
\hline & \multicolumn{3}{|c|}{ Moundou } & \multicolumn{3}{|c|}{ Pala } & \multicolumn{3}{|c|}{ Sarh } \\
\hline Month & $P_{\text {OUT }}$ & $C_{f}(\%)$ & $\begin{array}{c}E_{W T} \\
\text { (kWh/ } \\
\text { mon) }\end{array}$ & $P_{\text {OUT }}$ & $C_{f}(\%)$ & $\begin{array}{c}E_{W T} \\
(\mathrm{kWh} / \\
\text { mon) }\end{array}$ & $P_{\text {OUT }}$ & $C_{f}(\%)$ & $\begin{array}{c}E_{W T} \\
\text { (kWh/ } \\
\text { mon) }\end{array}$ \\
\hline January & 18.61 & $1.86 \%$ & $13,402.66$ & 15.96 & $1.6 \%$ & $11,493.18$ & 76.73 & $7.67 \%$ & $55,243.14$ \\
\hline February & 33.54 & $3.35 \%$ & $24,151.84$ & 15.89 & $1.59 \%$ & $11,441.89$ & 96.76 & $9.68 \%$ & $69,665.62$ \\
\hline March & 27.01 & $2.7 \%$ & $19,449.59$ & 24.44 & $2.44 \%$ & $17,597.86$ & 105.27 & $10.53 \%$ & $75,792.19$ \\
\hline April & 47.84 & $4.78 \%$ & $34,442.1$ & 20.33 & $2.03 \%$ & $14,641.1$ & 136.84 & $13.68 \%$ & $98,527.15$ \\
\hline May & 27.66 & $2.77 \%$ & $19,914.79$ & 13.07 & $1.31 \%$ & 9407.57 & 7.87 & $0.79 \%$ & 5664 \\
\hline June & 21.73 & $2.17 \%$ & $15,647.8$ & 10.78 & $1.08 \%$ & 7761.49 & 2.7 & $0.27 \%$ & 1943 \\
\hline July & 15.99 & $1.6 \%$ & $11,512.7$ & 2.4 & $0.24 \%$ & 1725.11 & 1.1 & $0.11 \%$ & 790 \\
\hline August & 18.85 & $1.89 \%$ & $13,574.65$ & 1.48 & $0.15 \%$ & 1069.07 & 0.94 & $0.09 \%$ & 676.66 \\
\hline September & 8.54 & $0.85 \%$ & 6151.73 & 3.1 & $0.31 \%$ & 2230.59 & 0.94 & $0.09 \%$ & 676.66 \\
\hline October & 17.59 & $1.76 \%$ & $12,663.71$ & 2.36 & $0.24 \%$ & 1701.16 & 1.47 & $0.15 \%$ & 1057.55 \\
\hline November & 6.72 & $0.67 \%$ & 4838.38 & 12.57 & $1.26 \%$ & 9052 & 16.67 & $1.67 \%$ & 12,000 \\
\hline December & 13.2 & $1.32 \%$ & 9506.73 & 32.42 & $3.24 \%$ & $23,342.94$ & 46.45 & $4.64 \%$ & $33,441.39$ \\
\hline
\end{tabular}


Table 9. Monthly variations of mean turbine VESTAS 2 MW/V80.

\begin{tabular}{lccccccccc}
\hline & \multicolumn{3}{c}{ Moundou } & \multicolumn{3}{c}{ Pala } & \multicolumn{3}{c}{ Sarh } \\
\hline Month & $\boldsymbol{P}_{\text {OUT }}$ & $C_{f}(\%)$ & $\begin{array}{c}E_{W T} \\
(\mathrm{kWh} / \\
\text { mon) }\end{array}$ & $\boldsymbol{P}_{\text {OUT }}$ & $C_{f}(\%)$ & $\begin{array}{c}E_{W T} \\
(\mathrm{kWh} / \\
\text { mon) }\end{array}$ & $P_{\text {OUT }}$ & $C_{f}(\%)$ & $\begin{array}{c}E_{W T} \\
(\mathrm{kWh} / \\
\text { mon) }\end{array}$ \\
\hline January & 33.23 & $1.66 \%$ & $23,927.4$ & 26.08 & $1.3 \%$ & $18,778.4$ & 130.21 & $6.51 \%$ & $93,751.06$ \\
February & 60.54 & $3.03 \%$ & $43,588.64$ & 27.56 & $1.38 \%$ & $19,844.78$ & 167.33 & $8.37 \%$ & $120,475.48$ \\
March & 47.84 & $2.39 \%$ & $34,442.22$ & 42.13 & $2.11 \%$ & $30,330.98$ & 183.12 & $9.16 \%$ & $131,845.55$ \\
April & 85.71 & $4.29 \%$ & $61,709.82$ & 34.54 & $1.73 \%$ & $24,867.3$ & 244.71 & $12.24 \%$ & $176,188.53$ \\
May & 47.62 & $2.38 \%$ & $34,287.9$ & 21.83 & $1.09 \%$ & $15,718.07$ & 11.7 & $0.58 \%$ & 8422.51 \\
June & 36.89 & $1.84 \%$ & $26,560.62$ & 16.67 & $0.83 \%$ & $12,004.92$ & 3.28 & $0.16 \%$ & 2365.2 \\
July & 26.69 & $1.33 \%$ & $19,213.97$ & 3.08 & $0.15 \%$ & 2217.82 & 0.93 & $0.05 \%$ & 669.58 \\
August & 28.97 & $1.45 \%$ & $20,857.96$ & 1.34 & $0.07 \%$ & 964.22 & 0.6 & $0.03 \%$ & 433.48 \\
September & 11.9 & $0.6 \%$ & 8568.4 & 3.21 & $0.16 \%$ & 2311.22 & 0.6 & $0.03 \%$ & 433.48 \\
October & 25.3 & $1.27 \%$ & $18,217.75$ & 2.66 & $0.13 \%$ & 1914.21 & 1.09 & $0.05 \%$ & 783.95 \\
November & 9.21 & $0.46 \%$ & 6631.96 & 17.53 & $0.88 \%$ & $12,618.15$ & 22.51 & $1.13 \%$ & $16,208.21$ \\
December & 21.56 & $1.08 \%$ & $15,526.74$ & 51.23 & $2.56 \%$ & $36,887.12$ & 74.34 & $3.72 \%$ & $53,523.47$ \\
\hline
\end{tabular}

Table 10. Annual power output and capacity factor of the selected wind turbine for the selected three locations.

\begin{tabular}{lcccccc}
\hline Location & \multicolumn{2}{c}{ BONUS $300 \mathrm{~kW} / \mathbf{3 3}$} & \multicolumn{2}{c}{ BONUS 1MW/54 } & \multicolumn{2}{c}{ VESTAS 2MW/V80 } \\
\hline & $\boldsymbol{P}_{e, \text { av }}(\mathrm{kW} /$ Year $)$ & $\boldsymbol{C}_{\boldsymbol{f}}(\%)$ & $\boldsymbol{P}_{e, \text { av }}(\mathrm{kW} /$ Year $)$ & $\boldsymbol{C}_{\boldsymbol{f}}(\%)$ & $\boldsymbol{P}_{e, \text { av }}(\mathrm{kW} /$ Year $)$ & $\boldsymbol{C}_{f}(\%)$ \\
\hline Moundou & 56.07 & 18.69 & 257.30 & 25.73 & 435.46 & 21.77 \\
Pala & 31.78 & 10.59 & 154.81 & 15.48 & 196.62 & 9.83 \\
Sarh & 115.50 & 38.50 & 493.72 & 49.37 & 840.42 & 42.02 \\
\hline
\end{tabular}

Table 11. Monthly variations of mean wind energy density $\left(\mathrm{kWh} / \mathrm{m}^{2}\right)$.

\begin{tabular}{|c|c|c|c|c|c|c|c|}
\hline Month & Jan. & Feb. Mar. Apr. & May & June & July & Aug. Sept. Oct. Nov. Dec. & Annual \\
\hline Moundou & 16.709 & 19.12417 .51621 .862 & 14.89 & 12.713 & 11.488 & 7.9445 .4425 .6895 .28610 .187 & 148.85 \\
\hline Pala & 10.435 & 12.46414 .59612 .5891 & 11.217 & 7.842 & 5.002 & 2.7732 .8623 .8335 .1379 .066 & 97.816 \\
\hline Sarh & 12.149 & 16.03520 .64433 .966 & 7.052 & 4.31 & 2.732 & 1.6511 .5981 .7182 .7176 .226 & 110.799 \\
\hline
\end{tabular}

Table 12. Standard deviation $(\sigma)$ of the selected three stations.

\begin{tabular}{lccccccccccccc}
\hline Month & Jan. & Feb. Mar. Apr. & May & June & July & Aug. & Sept. & Oct. & Nov. & Dec. Annual \\
\hline Moundou & 1.03 & 1.12 & 1.05 & 1.15 & 1.00 & 0.96 & 0.91 & 0.81 & 0.72 & 0.72 & 0.71 & 0.88 & 0.92 \\
Pala & 0.89 & 0.96 & 0.99 & 0.95 & 0.90 & 0.81 & 0.68 & 0.56 & 0.58 & 0.63 & 0.71 & 0.83 & 0.79 \\
Sarh & 0.47 & 0.58 & 0.69 & 1.09 & 0.77 & 0.66 & 0.56 & 0.48 & 0.48 & 0.49 & 0.48 & 0.46 & 0.60 \\
\hline
\end{tabular}

Table 13. Presentation of Weibull characteristics by seasons.

\begin{tabular}{|c|c|c|c|c|c|c|c|c|c|c|c|c|c|c|c|}
\hline \multirow[b]{2}{*}{ Seasons } & \multicolumn{5}{|c|}{ Moundou } & \multicolumn{5}{|c|}{ Pala } & \multicolumn{5}{|c|}{ Sarh } \\
\hline & $V(\mathrm{~m} / \mathrm{s})$ & $K$ & $C(\mathrm{~m} / \mathrm{s})$ & $V_{m p}$ & $V_{\max E}$ & $V(\mathrm{~m} / \mathrm{s})$ & $K$ & $C(\mathrm{~m} / \mathrm{s})$ & $V_{m p}$ & $V_{\max E}$ & $V(\mathrm{~m} / \mathrm{s})$ & $K$ & $C(\mathrm{~m} / \mathrm{s})$ & $V_{m p}$ & $V_{\max E}$ \\
\hline Winter & 3 & 3.4 & 3.34 & 3.01 & 3.83 & 2.6 & 3 & 2.91 & 2.51 & 3.49 & 1.9 & 1.24 & 2.03 & 0.53 & 4.44 \\
\hline Spring & 3.1 & 3.05 & 3.47 & 3.04 & 4.1 & 2.8 & 3.28 & 3.12 & 2.79 & 3.62 & 2.6 & 2.11 & 2.91 & 1.72 & 4.7 \\
\hline Summer & 2.6 & 3.05 & 2.91 & 2.55 & 3.43 & 2.1 & 3.61 & 2.29 & 2.09 & 2.6 & 1.7 & 3.54 & 1.89 & 1.72 & 2.14 \\
\hline Autumn & 2.1 & 2.9 & 2.32 & 1.99 & 2.8 & 1.9 & 3.13 & 2.09 & 1.83 & 2.46 & 1.4 & 2.58 & 1.57 & 1.22 & 2.07 \\
\hline
\end{tabular}


wind energy density during the period 1975-2010 of selected three stations in the Sudanese zone of Chad were evaluated. The analysis was done on the basis of Weibull distribution function with two parameters. Based on the results of this study, it can be concluded that:

1) The minimum monthly average wind speed of $1.4 \mathrm{~m} / \mathrm{s}$ in August, September, October and November in Sarh and a maximum value of $3.3 \mathrm{~m} / \mathrm{s}$ in Moundou in February and April were recorded. A maximum value of the average annual wind speed of $2.692 \mathrm{~m} / \mathrm{s}$ is obtained at Moundou.

2) The annual mean value of the Weibull $c$ scale parameter ranges from 2.099 $\mathrm{m} / \mathrm{s}$ to $3.007 \mathrm{~m} / \mathrm{s}$ whereas the annual value of the form parameter $k$ varies from 2.376 to 3.255. The highest of the values $c$ and $k$ are found in the Moundou and Pala stations, respectively. The average annual wind densities for Moundou, Pala and Sarh are $17.071 \mathrm{~W} / \mathrm{m}^{2}, 11.212 \mathrm{~W} / \mathrm{m}^{2}$ and $12.762 \mathrm{~W} / \mathrm{m}^{2}$, respectively.

3) The wind turbine in turn offers a more profitable possibility for the Sudanese zone of Chad with the wind turbine Vestas $2 \mathrm{MW} / 80$.

The wind power potential can be exploited to ensure sustainable development in the rural areas for pumping of water, heating of water, and production of electricity. The study recommends a long-term (at least ten years) wind speed data analysis for better understanding of energy potential and the design of suitable wind turbine for the selected cities.

\section{Acknowledgements}

We make a point of thanking the persons in charge of the National Meteorology for Chad, as the personnel who deal with the collection and the processing weather data on these sites, to have placed at our disposal the data which were used in our work.

\section{References}

[1] Vani, N. and Khare, V. (2013) Rural Electrification System Based on Hybrid Energy System Model Optimizing Using Homer. Canadian Journal of Basic and Applied Sciences, 1, 19-25.

[2] Sekar, M., Arunkumar, S. and Batasubramanian, V. (2014) PV-Wind Hybrid System for Supplying Power to Remote Locations. International Journal of Advanced Technology and Engineering Research (ITATER) on National Conference on "Renewable Energy Innovations for Rural Development', New Delhi.

[3] Keyhani, A., Ghasemi, M., Khanali, M. and Abbaszadeh, R. (2010) An Assessment of Wind Energy Potential as a Power Generation Source in the Capital of Iran, Tehran. Energy, 35, 188-201.

[4] Olayinka, S. and Olaolu, O. (2012) Assessment of Wind Energy Potential and the Economics of Wind Power Generation in Jos, Plateau State, Nigeria. Energy for Sustainable Development, 16, 78-83.

[5] Shown, M., Chaar, L. and Lamont, L. (2013) Overview of Wind Energy and Its Cost in the Middle East. Sustainable Energy Technologies and Assessments, 2, 1-11.

[6] Fyrippis, I., Axaopoulos, P. and Panayiotou, G. (2010) Wind Energy Potential Assessment in Naxos Island, Greece. Applied Energy, 87, 577-586.

[7] Al-Nhoud, O. and Al-Smairan, M. Assessment of Wind Energy Potential as a Power 
Generation Source in the Azraq South, Northeast Badia, Jordan. Modern Mechanical Engineering, 5, 87-96.

[8] Azad, A.K., Rasul, M.G., Khan, M.M.K., Ahasan, T. and Ahmed, S.F. (2014) Energy Scenario: Production, Consumption and Prospect of Renewable Energy in Australia. Journal of Power and Energy Engineering, 2, 19-25. https://doi.org/10.4236/jpee.2014.24004

[9] Al Zohbi, G., Hendrick P. and Bouillard, P. (2014) Evaluation du potentiel d'énergie éolienne au Liban. Revue des Energies Renouvelables, 17, 83-96.

[10] Azad, A.K., Alam, M.M. (2012) Wind Power for Electricity Generation in Bangladesh. International Journal of Renewable Energy Research, 3,172-178.

[11] Elamouria, M. and Ben Amar, F. (2008) Wind Energy Potential in Tunisia. Energy Assessment of the First Wind Farm Section of Sidi Daoud. Tunisia: Renewable Energy, 33, 758-768.

[12] Li, M. and Li, X. (2004) On the Probabilistic Distribution of Wind Speeds: Theoretical Development and Comparison with Data. International Journal of Exergy, 1, 237-255. https://doi.org/10.1504/IJEX.2004.005096

[13] M'Batna, J.-P. (2014) Énergies renouvelables: Quelles perspectives pour le Tchad, forum francophonie de l'innovation Namur fédération Wallonie-Bruxelles.

[14] Allanaïssem, Y. (2013) Les politiques publiques d'aménagement du territoire dans une dynamique de gouvernance décentralisée du système de développement territoriale durable au Tchad. Mémoirede Master.

[15] Darwish, A. and Sayigh, A. (1988) Wind Energy Potential in Iraq. Solar Technology and Wind, 5, 215-222.

[16] Elliott, D.L., Holladay, C.G., Barchet, W.R., Foote, H.P. and Sandusky, W.F. (1987) Wind Energy Resource Atlas of the United States. DOE/CH10094-4.

[17] Fadare, D.A. (2010) The Application of Artificial Neural Networks to Mapping of Wind Speed Profile for Energy Application in Nigeria. Applied Energy, 87, 934-942.

[18] Akdag, S.A., Bagiorgas, H.S. and Mihalakakou, G. (2010) Use of Two-Component Weibull Mixtures in the Analysis of Windspeed in the Eastern Mediterranean. Applied Energy, 87, 2566-2573.

[19] Akpinar, E.K. and Akpinar, S. (2005) An Assessment on Seasonal Analysis of Wind Energy Characteristics and Wind Turbine Characteristics. Energy Conversion and Management, 46, 1848-1867.

[20] Azad, A.K., Rasul, M.G. and Yusaf, T. (2014) Statistical Diagnosis of the Best Weibull Methods for Wind Power Assessment for Agricultural Applications. Energies, 7, 3056-3085. https://doi.org/10.3390/en7053056

[21] Akdag, S.A. and Dinler, A. (2009) A New Method to Estimate Weibull Parameters for Wind Energy Applications. Energy Conversion and Management, 50, 17611766.

[22] Costa Rocha, P.A., Sousa, R.C. and Andrade, C.F. (2012) Comparison of Seven Numerical Methods for Determining Weibull Parameters for Wind Energy Generation in the Northeast Region of Brazil. Applied Energy, 89, 395-400.

[23] Azad, A.K., Rasul, M.G., Islam, R. and Shishir, I.R. (2015) Analysis of Wind Energy Prospect for Power Generation by Three Weibull Distribution Methods. Energy Procedia, 75, 722-727.

[24] Keyhani, A., Ghasemi-Varnamkhasti, M., Khanali, M. and Abbaszadeh, R. (2010) An Assessment of Wind Energy Potential as a Power Generation Source in the Capital of Iran, Tehran. Energy, 35, 188-201. 
[25] Patel, M.R. (2006) Wind and Solar Power Systems. U.S. Merchant Marine Academy Kings Point, New York.

[26] Jamil, M., Parsa, S. and Majidi, M. (1995) Wind Power Statistics and Evaluation of Wind Energy Density. Renewable Energy, 6, 623-628.

[27] Raichle, B.W. and Carson, W.R. (2009) Wind Resource Assessment of the Southern Appalachian Ridges in the Southeastern United States. Renewable and Sustainable Energy Reviews, 13, 1104-1110.

[28] Ohunakin, O.S., Oyewola, O.M. and Adaramola, M.S. (2013) Economic Analysis of Wind Energy Conversion Systems Using Levelized Cost of Electricity and Present Value Cost Methods in Nigeria. International Journal of Energy and Environmental Engineering, 4, 2.

[29] Ucar, A. and Balo, F. (2009) Evaluation of Wind Energy Potential and Electricity Generation at Six Locations in Turkey. Applied Energy, 86, 1864-1872.

[30] Ramírez, P. and Carta, J.A. (2005) Influence of the Data Sampling Interval in the Estimation of the Parameters of the Weibull Wind Speed Probability Density Distribution: A Case Study. Energy Conversion and Management, 46, 2419-2438.

[31] Tar, K. (2008) Some Statistical Characteristics of Monthly Average Wind Speed at Various Heights. Renewable and Sustainable Energy Reviews, 12, 1712-1724.

[32] Azad, A.K. and Alam, M.M. (2010) Statistical Analysis of Wind Power Potential in Pakshey River Delta Region Bangladesh. Proceedings of the 13 th Asian Congress of Fluid Mechanics, Dhaka, 17-21 December 2010, 17-21.

[33] Islam, M.R., Saidur, R. and Rahim, N.A. (2011) Assessment of Wind Energy Potentially at Kudat and Labuan, Malaysia Using Weibull Distribution Function. Energy, 36, 985-992.

[34] Zhou, Y., Wu, W. and Liu, G. (2011) Assessment of Onshore Wind Energy Resource and Wind-Generated Electricity Potential in Jiangsu, China. Energy Procedia, 5, 418-422.

[35] Jaramillo, O.A. and Borja, M.A. (2004) Bimodel versus Weibull Wind Speed Distributions: An Analysis of Wind Energy Potential in La Venta, Mexico. Wind Engineering, 28, 225-234. https://doi.org/10.1260/0309524041211404

[36] Ouammi, A., Sacile, R. and Mimet, A. (2010) Wind Energy Potential in Liguria Region. Renewable and Sustainable Energy Reviews, 14, 289-300.

[37] Aksas, M. and Gama, A. (2011) Assessment of Wind and Solar Energy Resources in Batna, Algeria. Energy Procedia, 6, 459-466.

[38] Dieudonné, K.K., Kodji, D., Danwe, R. and Serge, D.Y. (2016) Wind Energy for Electricity Generation in the Far North Region of Cameroon. Energy Procedia, 93, 66-73.

[39] Paul, S.S., Oyedepo, S.O. and Adaramola, M.S. (2012) Economic Assessment of Water Pumping Systems Using Wind Energy Conversions in the Southern Part of Nigeria. Energy Explor Exploit, 30, 1-18. https://doi.org/10.1260/0144-5987.30.1.1

[40] Dieudonné, K.K., Bachirou, B.O., Michel, A., Danwe, R.I., Serge, D.Y., Oumarou, H. and Beda, T. (2016) Assessment of Wind Energy Potential and Cost Estimation of Wind-Generated Electricity at Hilltops Surrounding the City of Maroua in Cameroon. AIP Conference Proceedings, 1758, Article ID: 020012. https://doi.org/10.1063/1.4959388

[41] Louassa, S., Merzouk, M. and Guerri, O. (2012) Evaluation des performances de quatre types d'éolienne dans une Zonearide. Revue des Energies Renouvelables, 15, 533-545. 
[42] Oyedepo, S.O., Adaramola, M.S. and Paul, S.S. (2012) Analysis of Wind Speed Data and Wind Energy Potential in Three Selected Locations in South-East Nigeria. International Journal of Energy and Environmental Engineering, 3, 7.

https://doi.org/10.1186/2251-6832-3-7

\section{Scientific Research Publishing}

Submit or recommend next manuscript to SCIRP and we will provide best service for you:

Accepting pre-submission inquiries through Email, Facebook, LinkedIn, Twitter, etc. A wide selection of journals (inclusive of 9 subjects, more than 200 journals)

Providing 24-hour high-quality service

User-friendly online submission system

Fair and swift peer-review system

Efficient typesetting and proofreading procedure

Display of the result of downloads and visits, as well as the number of cited articles Maximum dissemination of your research work

Submit your manuscript at: http://papersubmission.scirp.org/

Or contact epe@scirp.org 